\title{
Effective Factors on Life Insurance Profitability (Case Study: Iranian Insurance Companies)
}

\author{
Omid Ahan Chideh'1, Ali Sorayaei ${ }^{2}$ \\ ${ }^{1}$ Business Management, Islamic Azad University, Babol, Iran \\ ${ }^{2}$ Department of Management, Islamic Azad University, Babol, Iran \\ Email: Oimd3641@gmail.com, a.sorayaei@gmail.com
}

How to cite this paper: Chideh, O.A. and Sorayaei, A. (2019) Effective Factors on Life Insurance Profitability (Case Study: Iranian Insurance Companies). Open Journal of Business and Management, 7, 546-555. https://doi.org/10.4236/ojbm.2019.72037

Received: February 27, 2019

Accepted: March 22, 2019

Published: March 25, 2019

Copyright () 2019 by author(s) and Scientific Research Publishing Inc. This work is licensed under the Creative Commons Attribution International License (CC BY 4.0).

http://creativecommons.org/licenses/by/4.0/

(c) (i) Open Access

\begin{abstract}
The aim of this research is to study the profitability of the insurance industry in Iran during the period of 20 years from 1993 to 2013. Research method is analytical and inductive post-event. Data related to the insurance and economic indicators are including the Premium of life insurance, Premium of non-life insurance, gross domestic product and inflation and profitability of Iranian insurance companies during the years 1993 to 2013 that were extracted from the economic and insurance forms. The regression model and ARDL time series technique were used for data analysis. The research results showed that the Premium of life insurance has a positive effect on the profitability of insurance companies in Iran, but the Premium of non-life insurance has not had a significant effect on profitability, the economic indexes of research, namely GDP and inflation, have a positive and negative impact on the profitability of insurance companies in Iran, respectively.
\end{abstract}

\section{Keywords}

Profitability, Premium of Life Insurance, Premium of Non-Life Insurance, Inflation, GDP

\section{Introduction}

Insurance is a legal term and in the word means insuring or guaranteeing or preserving against accidents that is the fear of them. The insurance enables individuals who suffer harm, loss or unwanted incident to compensate for the consequences of this unfortunate event [1]. Rapid changes in people's lives have exposed them to various risks, such as loss of estate and property, work-related injuries, inability, and disability and death. Since the general public is out of danger and endeavors to ensure their safety (including financial security), various 
types of prevention and risk reduction methods have been used, especially in the financial dimension in human life. In this regard, insurance as one of the most important tools in the modern civilized world has a significant role in reducing of the risk and providing of the financial and mental security. Today, various types of insurance are formed to reduce the risks people face to them. To reduce the adverse effects of accidents, life insurance is recognized as the most effective and most accepted tool in many countries of the world. Life insurance assures people that they can have a better life in the future, so it is very effective in terms of material well-being and intellectual and spiritual well-being. It can also act as a means of saving for people [2]. Today, people are living in an environment that is increasingly moving towards a service-based economy. Other services are not a small part of the economy, but also it is considered as the heart of value creation in the economy. Today, services are not limited to banking, post, insurance, health and education services, but most of the products we buy that include elements of service. In recent years, growing service has become one of the main trends in the world. The movement and change in the service-based economy has been comprehensive since 1970 [3]. Customers often compare the services offered by an institution to their expected services. They will return again to the institute that provided services are more than or at least equal to their expected services [4]. Life insurance represents the growth of every nation's culture, a culture that it needs to be expanded daily. Developing countries are always faced with economic fluctuations. The household economy is also heavily influenced by the low incomes of households, not the Head of household! In these countries, the Head of households' incomes are planned in the form of specific and predetermined household expenditures [5]. Insurance companies, by choosing appropriate financial structures, try to increase their survival and profitability. The capital of these companies is composed of two parts. First: The amount of needed capital, the second: the combination of financing sources. Capital expenditures are the items in which the company invests their funds in it and the right side of the company's balance sheet reflects investment or capital expenditures. Funds capital resources that the company invests and these items are including the company's owners' equity (equity) bonds and loans (bank loans or bonds). The manager of finance must try to provide the necessary funds from the places that provide the highest benefit to the company and the lowest risk.

Investment opportunities are different for people. The average returns generated by these opportunities form the expected rate of return for individuals in economic activities. Now, if insurers do not pay attention to opportunity costs according to the optional nature of life insurance, they cannot succeed in selling life insurance. Today, the time value of insurers' money is being paid for the sale of life insurance in advanced economies. The future value of all insurance premiums paid by insurers during the insurance period must be at least equal to the received compensation value. Optimal management of cash flows from the sale of life insurance and the use of investment opportunities will respect the cus- 
tomers' ability to sell these insurance policies in addition to providing redundancy to offset the risks arising from the risks. Insurers can consider the average of all investment returns in different markets as a rate of interest in life insurance policies to Compensation of the rate of return of their insurers.

\section{Literature Review}

\subsection{Insurance Companies' Performance}

The main purpose of implementing a performance management system, it is to ensure that the organization and all its subsystems (including processes, departments, employee decisions) work together in an optimal manner to achieve the desired results of the organization [7]. Insurance companies are different from one another in different ways. These companies can be based on the range of activities (local or international markets), the field of activity (direct or reliant), the type of activity (life insurances, property or complex insurance), the level of supervision applied to them and are grouped other components. The operations of insurance companies are divided into three areas of professional (technical) activities, financial services and administrative services. This part which is the main distinguishing feature of these institutions or organizations and at the same time, it is a matter of sharing between insurance companies, first it is related to the technical activities and, to a certain extent, their financial activities (the same source).

\subsection{The Presentation Quality of Insurance Services}

Today, service industries play an essential and important role in the economic growth and development of the countries and the role, importance and position of the insurance industry as a supportive industry is not covered by anyone. At the same time, increasing of the competition in the insurance industry has led most managers of this industry to find a lasting business presence. Therefore, they have to find and act on the approaches to obtain more customer satisfaction (Figure 1).

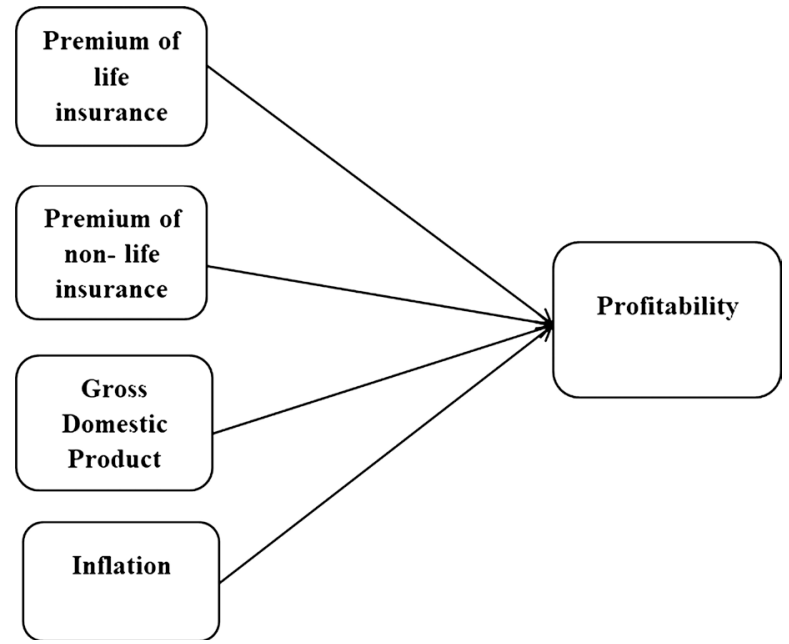

Figure 1. Conceptual model of research [6]. 
One of the ways to achieve this problem, it is improvement of the quality of insurance services. In this regard, the importance of the personnel of this industry is not covered by anyone, and only satisfied employees can keep customers satisfied. Therefore, it can be concluded that improvement of the quality of internal services of the organization leads to increasing the satisfaction of foreign customers. The most important goal of the service centers is the presentation of satisfactory, cost-effective services in accordance with good scientific standards and in the shortest possible time. Quality is one of the effective factors on success of service organizations. The presentation of quality services is leads to increasing the productivity and customer satisfaction and reduces the organization's costs. The central customer is the first strategy of all organizations of the world. Quality of service is the biggest problem facing to the service organizations. Providing the sufficient information on the content of customer perceptions of service quality can help organizations identify areas and dimensions that affect the competitive advantage of organizations. A successful service company must first sell the job to employees and provide employee satisfaction and then it can provide services to customers, in simple terms, internal customer satisfaction is very important to the company's success. In fact, the concept of internal marketing states that the organization employees are the first market of the organization.

\subsection{Profitability of Insurance Companies}

Although the profitability of Iranian insurance companies (considering their statehood) is much higher than that of foreign insurance companies, but in terms of return on investment, there is no significant difference between them. The comparison between these two levels is much higher than that of foreign insurance companies and Iranian insurance companies do not have a good performance in earning money by considering the total resources that is available to these companies. The desire to provide quality services plays an important role in the insurance industry, because the quality of services is vital for the survival and profitability of insurance companies [8]. Kandampully are mentioned the increasing of the profitability of insurance companies and the reducing of customer sensitivity to price changes from the consequences of loyal customers in the insurance industry [9]. We know that in the Iranian insurance market, which is already located on liberation and privatization way, the price changes of competing corporations can have a huge impact on the organization. Loyal customers will increase the profitability of the service provider, and we know that profitability is an indicator of organizational performance measurement. Improving organizational performance means increasing the credibility and reputation of the organization, which in turn could have good implications for the organization. The lack of development of the capital market and in particular the lack of development of diverse financial instruments, the statehood of insurance companies and the unwillingness of insurance companies to increase their profitabil- 
ity in Iran until the major part of focused financial resources on them is lead to banking system instead of producing productive investments, including the securities market. According to available studies, from the end of the years 1989 to 1993, the total of financial resources of the insurance companies, which is estimated at 2875.3 billion Rials, it was only 57.6 billion Rials directed towards the stock market, which represents a slight percentage equal to 2 percent [3].

\subsection{The Concept of Inflation Rate}

Inflation has several causes that are most notably inflation as a monetary phenomenon, inflation due to demand pressure, and inflationary costs. Inflation fluctuations may be being important and effective in making managerial decisions about financing. Considering that the increase of inflation in the long-term leads to improvement of inflows of cash flows to the company, it will also increase the savings and company undivided profits levels. Since the one of the company finance sources is the use of company's accumulated profits, so, the financial leverage of the company will decrease by financing through accumulated profits which indicates a negative correlation between the inflation rate and the capital structure [10]. It is recalled that the effect of the inflation rate on the capital structure has been studied in Bokpin [11] and Song shin and Adrian [12], Drobetz et al. [10], which all confirmed the negative impact of inflation on capital structure.

\section{Background}

Shuanglin and Wei [13] are reviewed the profitability of Chinese companies. They consider the factors such as the growth of Non-Exchange companies, stagnant assets, debt rates, and international trade and they concluded that the growth of Non-Exchange companies were positively associated with the profitability of Exchange companies.

Komonen [14] was reviewed the study by titled "Effective factors on the profitability of manufacturing companies" and he studied the effect of factors such as sales (size), labor, raw materials, capital and maintenance costs of other factors on the profits of manufacturing companies. His study results indicated that sales and labor costs had a greater impact on the profits of manufacturing companies than other variables.

Chen et al. [15] were conducted the research by titled "Influence of capital structure and operational risk on profitability of life insurance industry in Taiwan" and they examined the capital structure of life insurance companies and presented a theoretical model. They concluded that capital structure had a significant negative impact on operational risk, as well as operational risk, which had a negative relationship with the profitability of life insurance companies.

Zubairi [16] is examined the impact of effective economic and financial indicators on the profitability of Pakistani companies. He has been selected asset returns and salary shareholders returns as profitability measures and the variables 
influencing profitability were liquidity, financial leverage, and annual growth of earnings, average of stock prices and GDP in his research. He found that GDP (a foreign factor) had a direct and significant relationship with the profitability of the study period. Although there is a direct relationship between liquidity, average of stock prices and annual growth of earnings with profitability.

\section{Research Hypotheses}

1) The Premium of life insurance is effective on the profitability of insurance companies.

2) The Premium of non-life insurance is effective on the profitability of insurance companies.

3) GDP is effective on the profitability of insurance companies.

4) Inflation is effective on the profitability of insurance companies.

\section{Research Method}

The method of this research is inductive and post-event (using past information) and its statistical method is a cross-sectional correlation. The statistical population is (economic data) of the country, and since the studied society) is limited in this research (the total of Iranian insurance companies, it was decided to examine the whole of society and avoid the sampling. The period of research is 20 years from 1993 to 2013.

Research model: the present study examines the relationship between 4 variables with profitability [6].

$$
\text { Prof }=\alpha_{0}+\beta_{1} P L I+\beta_{2} P N L I+\beta_{3} G D P+\beta_{4} I N F+\varepsilon
$$

In this research, profitability ( $\operatorname{Prof}_{\mathrm{t}}$ ) is considered as a dependent variable.

$P L I=$ Premium of life insurance. $P N L I=$ Premium of non-life insurance. $G D P=$ Gross Domestic Product. INF = Inflation, are considered as independent variables.

After collecting the research data, the Dickey Fuller test was performed to test the data stability and after determining the degree of stability, there are the research variables from one of the software Eviews and Macrofit 7 and the ARDL method was used to study the long-run relationship between variables.

Estimation of the research model: In this section, firstly, the model variables stability is investigated. Then, the model estimates for three dynamics, longterm, and short-run relationships, and finally performs the stability test.

\section{Variables stability test}

In this section, using the Phillips-Peron unit root test, the reliability and non-stability of the variables were studied to determine the degree of variables accumulation. Then, the relationship between the variables was investigated by determining the optimal interruptions by using the micro fit software 4 for the ARDL model, and the meaningful variables will be examined. Then it is turn to estimate the long-time coefficients of the variables. This work is done those long-term effects of model variables to determine on profitability (Premium of 
life insurance, Premium of non-life insurance, GDP, inflation rate). In the next step, we will estimate the error-correction model associated with the long-term equilibrium relation from the ARDL method. As shown in Table 1, the variables of economic growth, financial development, open trade, and inflation rate are static at the first level of difference. The Phillips-Peron test should be larger than the MacKinnon critical values; In this case, the reliability of the time series variables is confirmed at the relevant significance level (1\%,5\%, and $10 \%)$.

\section{Estimation of ARDL model and findings analysis}

Dynamic relationship: The ARDL method has been used to estimate longterm relationships between model variables and dynamic analysis. In this method, the number of optimal lags is determined by one of the criteria of Akaike1, Schwartz 2 and Henan-Quinn 3. According to the Schwarz criterion saves the number of interruptions, this criterion is used to determine the number of optimal interruptions.

Table 2 shows the dynamic equation estimation that the computational equation obtains equal to -3.5127 to investigate the existence of a long-time relationship based on this equation, because $t$ corresponds to Banerjee, Dolado and Master Table is more than -3.28 in absolute terms. The zero assumption is rejected

Table 1. The results of root test of generalized unit dickey fuller.

\begin{tabular}{|c|c|c|c|c|}
\hline \multirow{2}{*}{ Variable } & \multirow{2}{*}{ Symbol } & \multirow{2}{*}{ difference } & Dickey Fuller & \multirow{2}{*}{ result } \\
\hline & & & Intercept & \\
\hline Profitability & PROF & level & -5.00 & $\mathrm{I}(0)$ \\
\hline \multirow[b]{2}{*}{ Premium of life insurance } & \multirow[b]{2}{*}{ PLI } & level & -3.42 & \multirow[b]{2}{*}{$\mathrm{I}(1)$} \\
\hline & & First level & -4.84 & \\
\hline \multirow[b]{2}{*}{ Premium of non-life insurance } & \multirow[b]{2}{*}{ PNLI } & level & -1.05 & \multirow[b]{2}{*}{$\mathrm{I}(1)$} \\
\hline & & First level & -7.39 & \\
\hline \multirow{2}{*}{ Gross Domestic Product } & \multirow{2}{*}{ GDP } & level & -2.16 & \multirow{2}{*}{$\mathrm{I}(1)$} \\
\hline & & First level & -5.31 & \\
\hline Inflation & INF & level & -3.03 & $\mathrm{I}(1)$ \\
\hline
\end{tabular}

Table 2. The results of dynamic relation estimation $(1,0,0,0)$ of the ARDL model with SBC standard.

\begin{tabular}{|c|c|c|c|c|c|c|}
\hline \multicolumn{2}{|l|}{ variables } & symbol & Coefficients & Standard deviation & t-statistic & Significant \\
\hline \multicolumn{2}{|c|}{ Logarithm of profitability in the first interruption $(-1)$} & L PROF $(-1)$ & 0.73748 & 0.074734 & 9.8680 & 0.000 \\
\hline \multicolumn{2}{|c|}{ Premium of life insurance Logarithm } & PLI & 0.071058 & 0.024608 & 2.8876 & 0.009 \\
\hline \multicolumn{2}{|c|}{ Premium of non-life insurance Logarithm } & PNLI & -0.12809 & 0.10314 & -1.2419 & 0.229 \\
\hline \multicolumn{2}{|c|}{ Gross Domestic Product Logarithm } & GDP & 0.32351 & 0.11024 & 2.9346 & 0.007 \\
\hline \multicolumn{2}{|l|}{ Inflation rate } & LINF & -0.039075 & 0.012513 & -3.01227 & 0.006 \\
\hline \multicolumn{2}{|c|}{ Intercept (constant number) } & $\mathrm{C}$ & -0.53230 & 1.7802 & -0.29901 & 0.768 \\
\hline 1.80 & D.W & & & 9.80 & \multicolumn{2}{|c|}{ R-Squared } \\
\hline 9.80 & R-Bar-Squared & & & 442.2084 & \multicolumn{2}{|l|}{ F-stat } \\
\hline
\end{tabular}


based on non-existence of long-term relationship and its existence is accepted. The coefficient is 0.98 , which means that $98 \%$ of the variation of the dependent variable is explained by the explanatory variables. Also, the D.W statistic has been used to investigate the existence or non-existence of self-correlation, because the coefficient of this statistic is 1.80 . Therefore, the assumption of selfcorrelation is rejected in the model, and the F statistic is 442.2084, which indicates the power of the pattern's explanation.

Diagnostic tests perform to check the accuracy of the estimated dynamic pattern. The zero hypotheses cannot be rejected based on non-existence serial correlation between sentences, correct statement of equation, normal distribution of waste sentences and variance homology (Table 3).

Long-term relationship: The results of estimating the long-time relationship are shown in Table 4.

Short-time relationship and adjustment speed: The results of short-term pattern estimation showed that ECM coefficient is estimated to be -0.26 , which it's the negative and meaningfulness confirms the Cointegration between the model variables. This means that $26 \%$ of the template imbalance is adjusted in each period and approaches its long-time trend and suggests that it takes about $3.84(1 / 0.26=3.84)$ years to adjust short-time imbalances toward long-term equilibrium.

\section{Conclusions}

According to the results of the 1 hypothesis test, with respect to the significance level (less than 0.05), the premium of life insurance variable is estimated to be positive and significant. On the other hand, Profitability increases $0.27 \%$ amount with a one-percent increasing of the premium of life insurance.

According to the results of the 2 hypothesis test, with respect to the significance level (less than 0.05), the premium of life insurance variable is estimated to

Table 3. Diagnostic tests.

\begin{tabular}{cccc}
\hline Serial Correlation & $0.17817(0.673)$ & Normality & $0.49956(0.779)$ \\
Functional Form & $0.27593(0.599)$ & Heteroscedasticity & $2.7735(0.096)$ \\
\hline
\end{tabular}

Table 4. The results of estimating the long-time relationship $(1,0,0,0)$ of the ARDL model with SBC standard.

\begin{tabular}{cccccc}
\hline variables & symbol & Coefficients & $\begin{array}{c}\text { Standard } \\
\text { deviation }\end{array}$ & t-statistic & Significant \\
\hline $\begin{array}{c}\text { Logarithm of profitability in } \\
\text { the first interruption }\end{array}$ & LPLI & 0.27067 & 0.034398 & 7.8688 & 0.000 \\
$\begin{array}{c}\text { Premium of life insurance Logarithm } \\
\text { Premium of non-life insurance Logarithm }\end{array}$ & LPNLI & -0.48792 & 0.35481 & -1.3752 & 0.185 \\
$\begin{array}{c}\text { Gross Domestic Product Logarithm } \\
\text { Inflation rate }\end{array}$ & INF & -0.65282 & 0.12272 & 5.3197 & 0.000 \\
\hline
\end{tabular}


be negative and non-significant. In other words, premium of non-life insurance does not have a significant effect on the profitability of insurance companies.

According to the results of the 3 hypothesis test, with regard to the significance level (less than 0.05), GDP variable is positive and significant. On the other hand, profitability will increase by 0.65 percent with a one-percent increase in GDP.

According to the results of the 4 hypothesis test, with regard to the significance level (less than 0.05), relation between profitability and inflation rate is negative and significant. The profitability will decrease by 0.14 percent with a one-percent increase in profitability and inflation rate.

Finally, the results of this study are consistent with the study of [16], which examined the impact of effective economic and financial indicators on the profitability of Pakistani companies. The variables that influenced profitability in the research of liquidity, financial leverage, annual growth of earnings, average of stock prices and GDP, and the results of GDP (a foreign factor) had a direct and significant relationship with the profitability of the period under study.

\section{Conflicts of Interest}

The authors declare no conflicts of interest regarding the publication of this paper.

\section{References}

[1] Karami, M. (2009) The Evaluation of Quality in Providing Main and Complementary Insurance Services from Inpatients' Point of View in Kashan Hospitals: 2008. The Journal of Urmia Nursing and Midwifery Faculty, 7, 100-105.

[2] Mahdavi, G. and Majed, V. (2014) The Effect of Quantitative and Qualitative Factors on Iranian Life Insurance Demand.

[3] Karimi, M. and Kashani, B.H. (2012) Customer Preference of Private Insurance Covers in Iran. African Journal of Business Management, 6, 4276.

[4] Ganguli, S. and Roy, S.K. (2011) Generic Technology-Based Service Quality Dimensions in Banking: Impact on Customer Satisfaction and Loyalty. International Journal of Bank Marketing, 29, 168-189. https://doi.org/10.1108/02652321111107648

[5] Leland, H.E. (1980) Who Should Buy Portfolio Insurance? The Journal of Finance, 35, 581-594. https://doi.org/10.1111/j.1540-6261.1980.tb02190.x

[6] Jarraya, B. and Bouri, A. (2014) Optimal Production Plan and Profit Efficiency in European Non-Life Insurance Companies. Procedia Economics and Finance, 13, 69-81. https://doi.org/10.1016/S2212-5671(14)00431-6

[7] Seyed, J.S.R., Esfidani, M.R. and Esfidani, H. (2011) Designing a Neural Network for Selecting the Internet Marketing Strategy.

[8] Seyyed Javadin, R. and Kimasi, M. (2005) Quality Management Services. Neghah Danesh Publication, Tehran.

[9] Kandampully, J. and Hu, H.H. (2007) Do Hoteliers Need to Manage Image to Retain Loyal Customers? International Journal of Contemporary Hospitality Management, 19, 435-443. https://doi.org/10.1108/09596110710775101

[10] Drobetz, W. and Grüninger, M.C. (2007) Corporate Cash Holdings: Evidence from 
Switzerland. Financial Markets and Portfolio Management, 21, 293-324. https://doi.org/10.1007/s11408-007-0052-8

[11] Bokpin, G.A. (2009) Macroeconomic Development and Capital Structure Decisions of Firms: Evidence from Emerging Market Economies. Studies in Economics and Finance, 26, 129-142. https://doi.org/10.1108/10867370910963055

[12] Adrian, T. and Shin, H.S. (2009) Money, Liquidity, and Monetary Policy.

[13] Lin, S. and Rowe, W. (2006) Determinants of the Profitability of China's Regional SOEs. China Economic Review, 17, 120-141. https://doi.org/10.1016/j.chieco.2005.05.001

[14] Komonen, K. (2002) A Cost Model of Industrial Maintenance for Profitability Analysis and Benchmarking. International Journal of Production Economics, 79, 15-31. https://doi.org/10.1016/S0925-5273(00)00187-0

[15] Chen, J.-S., et al. (2009) Influence of Capital Structure and Operational Risk on Profitability of Life Insurance Industry in Taiwan. Journal of Modelling in Management, 4, 7-18. https://doi.org/10.1108/17465660910943720

[16] Zubairi, H.J. (2010) Impact of Working Capital Management and Capital Structure on Profitability of Automobile Firms in Pakistan. 